\title{
PENGARUH OLEORESIN DAUN JERUK PURUT PADA EDIBLE COATING TERHADAP KUALITAS SOSIS BEKU
}

\author{
EFFECT OF KAFFIR LIME LEAVES OLEORESIN EDIBLE COATING ON FROZEN \\ SAUSAGE QUALITY
}

\author{
Rohula Utami $^{(1)}$, Lia Umi Khasanah ${ }^{(1)}$, Kawiji ${ }^{(1)}$, Annisa Widia Utami( ${ }^{(1)}$ \\ ${ }^{(1)}$ Program Studi Ilmu dan Teknologi Pangan, Fakultas Pertanian, Universitas Sebelas Maret \\ J1. Ir Sutami 36 A Surakarta \\ email : rohula_utami@yahoo.com
}

\begin{abstract}
The aim of this study was to determine the effect of two-stage kaffir lime (Citrus hystrix DC) leaves oleoresin on microbiological characteristic (TPC) and physicochemical (color, pH, TBA, and TVB) of beef sausages during storage $\left(-10 \pm 2{ }^{\circ} \mathrm{C}\right)$. This study used Complete Randomized Design $(C R D)$ with one factor that is the concentration of two-stage kaffir lime leaves oleoresin in edible coating at 0\%; 0.01\%; and 0.075\%. The observation was made at 0, 1, 2, 3, and 4 months. The results showed that two-stage kaffir lime leaves oleoresin on edible coating beef sausage affecting microbiological and oxidative damages of beef sausage. The addition of two-stage kaffir lime leaves oleoresin lead to inhibition of microbial growth in beef sausages, and the increasing of TVB value as freshness parameter can be suppressed. Presence of citronellal on two-stage kaffir lime leaves oleoresin effected TBA values, while the $\mathrm{pH}$ value and color can be maintained during storage. Enrichment of two-stage kaffir lime leaves oleoresin could extend shelf life of beef sausage.
\end{abstract}

Keywords: beef sausage, Citrus hystrix DC, edible coating, frozen, kaffir lime leave

\section{ABSTRAK}

Tujuan penelitian ini adalah untuk mengetahui pengaruh penambahan berbagai konsentrasi oleoresin daun jeruk purut dua tahap terhadap karakteristik mikrobiologis (TPC) dan fisiko-kimia (warna, pH, TBA, dan TVB) sosis daging sapi selama penyimpanan pada suhu $-10 \pm 2^{\circ} \mathrm{C}$. Rancangan percobaan yang digunakan adalah Rancangan Acak Lengkap (RAL) dengan satu faktor yaitu konsentrasi oleoresin daun jeruk purut dua tahap pada edible coating sebesar 0\%; 0.01\%; dan $0.075 \%$. Pengamatan dilakukan pada bulan ke 0, 1, 2, 3, dan 4. Dari hasil penelitian diketahui bahwa dengan penambahan oleoresin daun jeruk purut dua tahap pada edible coating mempengaruhi kerusakan mikrobiologis dan oksidatif sosis daging sapi. Dengan penambahan oleoresin daun jeruk purut (Citrus hystrix DC) dua tahap maka terjadi penghambatan pertumbuhan mikroba pada sosis daging sapi, serta peningkatan nilai TVB sebagai parameter kesegaran dapat ditekan. Adanya sitronelal pada oleoresin daun jeruk purut dua tahap mempengaruhi nilai TBA. Sedangkan nilai $\mathrm{pH}$ dan warna dapat dipertahankan selama penyimpanan. Penambahan oleoresin daun jeruk purut dua tahap pada edible coating dapat meningkatkan umur simpan sosis daging sapi.

Kata kunci: Citrus hystrix DC, daun jeruk purut, edible coating, pembekuan, sosis daging sapi

\section{PENDAHULUAN}

Salah satu produk olahan daging yang sudah terkenal dan digemari masyarakat adalah sosis. Sosis merupakan produk yang dibuat dari daging yang telah dicincang kemudian dihaluskan dan diberi bumbu-bumbu, dimasukkan ke dalam pembungkus buatan, dengan atau tidak dimasak. Berdasarkan syarat mutu sosis dalam SNI 01-3020-1995, kandungan air maksimal dalam sosis yaitu $67 \%$ dan kandungan lemak maksimal $25 \% \mathrm{~b} / \mathrm{b}$. Kandungan air, protein maupun lemak yang tinggi menjadikan sosis makanan yang mudah rusak (perishable) karena adanya kerusakan baik oksidatif maupun mikrobiologis.

Meskipun dibekukan, produk sosis proses segar dan masak dapat mengalami otooksidasi lemak. Otooksidasi lemak dapat menyebabkan penyimpangan flavor dan dapat menurunkan nilai nutrisi daging. Selain itu, baik daging maupun sosis rentan terhadap bakteri pembusuk Pseudomonas yang mendominasi pada suhu dingin. Oleh karena itu, perlu adanya proses pengawetan agar sosis tidak cepat rusak dan mempunyai daya simpan yang cukup lama.

Ketertarikan konsumen terhadap 
produk pangan bermutu, sehat, dan aman yang terus meningkat memberikan tantangan bagi pengolah makanan untuk mengembangkan konsep edible film dan coating fungsional sebagai solusi yang potensial. Edible film maupun coating memiliki keunggulan yaitu bersifat biodegradable dan aman bagi produk yang dikemas maupun untuk dikonsumsi. Selain itu juga dapat menghambat transfer massa dan oksidasi yang dapat menimbulkan perubahan warna, flavor, dan tekstur (Ozcakmak dan Ozturk, 2012). Keunggulan edible film dan coating sebagai carrier senyawa antimikroba lebih banyak dikembangkan dewasa ini karena selain berfungsi sebagai penghambat aktivitas mikroba, sifat hambat (barrier) dari edible film juga dapat meningkat sehingga dapat memperpanjang umur simpan produk.

Rekomendasi produk herbal sebagai pengawet makanan yang aman atau generally recognized as safe (GRAS) di beberapa negara maju menyebabkan ketertarikan terhadap pengawet makanan alami yang berasal dari tanaman. Komoditi yang memiliki potensi untuk dikembangkan aplikasinya di Indonesia adalah daun jeruk purut. Komponen utama pada daun jeruk purut adalah sitronelal, yaitu sekitar $65.99 \%$ (Munawaroh dan Handayani, 2010). Senyawa lain yang terkandung dalam daun jeruk purut adalah sitronelol, linalol, nerolidol, dan geraniol. Oleoresin daun jeruk purut dapat diperoleh dengan dua cara, yaitu ekstraksi langsung dan ekstraksi tidak langsung. Pada ekstraksi langsung, oleoresin dibuat hanya melalui proses ekstraksi. Sedangkan ekstraksi tidak langsung melibatkan proses destilasi sebelum dilakukan proses ekstraksi. Oleoresin yang didapat dari proses ektraksi dan evaporasi dicampur dengan minyak atsiri yang diperoleh saat proses destilasi sehingga menghasilkan oleoresin dua tahap. Diperolehnya minyak atsiri daun jeruk purut sebelum proses ekstraksi dapat mengurangi potensi hilangnya kandungan minyak atsiri selama proses ekstraksi maupun evaporasi.

Dari penelitian yang dilakukan oleh Achmad (2012), kandungan minyak atsiri dan sitronelal pada oleoresin daun jeruk purut dua tahap berturut-turut sebesar $54.39 \%$ dan $43.43 \%$. Kandungan minyak atsiri daun jeruk purut, khususnya sitronelal berpotensi sebagai senyawa antimikroba (Kotan et al., 2007; Singh et al., 2006). Telah dilaporkan pula ekstrak daun jeruk purut memiliki aktivitas antimikroba (Nanasombat dan Lohasupthawee, 2005; Chanthaphon et al., 2008; Wungsintaweekul et al., 2010).

Telah banyak penelitian mengenai pemanfaatan tanaman sebagai pengawetan alami dalam sosis. Bawang putih (Dewi et al., 2010), minyak jintan (Krkic et al., 2013), ekstrak daun kemangi (Safraz et al., 2013), dan tepung kulit tomat (Salem, 2013) merupakan bahan yang telah dimanfaatkan dalam proses pengawetan sosis. Namun, belum ada pemanfaatan oleoresin daun jeruk purut sebagai pengawet sosis daging sapi melalui edible coating. Oleh sebab itu penelitian ini dilakukan untuk mengaplikasikan oleoresin daun jeruk purut pada produk sosis daging sapi melalui edible coating. Dan untuk mengetahui pengaruh penambahan oleoresin daun jeruk purut dalam edible coating sosis daging sapi untuk menghambat kerusakan oksidatif dan mikrobiologis.

\section{METODE PENELITIAN}

\section{Bahan}

Bahan dalam pembuatan oleoresin yaitu daun jeruk purut (Citrus hystrix DC) segar yang diperoleh dari Pasar lokal Surakarta, dan pelarut etanol 96\% (EMerck). Bahan untuk edible film adalah tepung tapioka (Rose Brand), aquades, dan gliserol (E-Merck). Sedangkan untuk aplikasi edible film, bahannya yaitu sosis sapi "Besto" diperoleh dari daerah Surakarta dan kemasan PP dengan ketebalan 0,8 mm.

\section{Tahapan Penelitian}

\section{Pembuatan Oleoresin Jeruk Purut Dua Tahap}

Oleoresin daun jeruk purut dua tahap merupakan campuran dari minyak atsiri daun jeruk purut dan oleoresin ampas sisa destilasi minyak atsiri. Potongan daun jeruk purut segar ukuran $1.5 \mathrm{~cm}$ diproses dengan cara destilasi uap/air dengan waktu kontak 4 jam 
untuk mendapatkan minyak atsiri. Ampas daun dari sisa destilasi dikeringanginkan hingga kadar air ampas daun $15 \pm 2 \%$. Ekstraksi ampas daun jeruk purut dilakukan dengan cara maserasi pada suhu $73^{\circ} \mathrm{C}$ selama 5 jam 14 menit. Pelarut yang digunakan dalam proses ekstraksi daun jeruk purut adalah etanol $96 \%$ dengan perbandingan 1 : 5. Penguapan pelarut dari filtrat hasil ekstraksi dilakukan menggunakan rotary evaporator vacuum (IKA RV 10 Basic) pada suhu $80^{\circ} \mathrm{C}$ dengan kecepatan $100 \mathrm{rpm}$ hingga didapatkan oleoresin yang kental dan tidak ada tetesan etanol selama 30 menit pada labu penampung pelarut Achmad (2012). Minyak atsiri dan oleoresin dicampur hingga homogen menggunakan vortex (Heidolp REAX) untuk memperoleh oleoresin daun jeruk purut dua tahap.

\section{Pembuatan Larutan Edible Coating}

Larutan edible coating dibuat dari $5 \mathrm{~g}$ tepung tapioka (Rose Brand) dengan penambahan $100 \mathrm{ml}$ aquades yang dipanaskan pada suhu $60^{\circ} \mathrm{C}$ hingga tergelatinisasi dan diaduk secara kontinu menggunakan magnetic stirrer (IKA C-MAG HS 7). Larutan ditambahkan $2 \mathrm{ml}$ gliserol (EMerck) dan diaduk selama 30 menit pada suhu $60^{\circ} \mathrm{C}$. Larutan edible coating yang dihasilkan lalu didinginkan hingga suhu ruang sebelum ditambahkan dengan oleoresin daun jeruk purut dua tahap. Oleoresin daun jeruk purut dua tahap ditambahkan pada larutan edible coating sebanyak $0.01 \%$ dan $0.075 \%(\mathrm{~b} / \mathrm{v})$.

\section{Aplikasi Edible Coating Secara Coating Pada Sosis Daging Sapi}

Larutan edible coating dengan variasi konsentrasi penambahan oleoresin $(0 \%$; $0.01 \%$; dan $0.075 \%$ ) diaplikasikan pada sosis daging sapi "Besto" dengan cara mencelupkan sosis ke dalam larutan edible coating. Pencelupan dilakukan dua kali agar merata. Kemudian sosis digantung dan dikeringkan dengan menggunakan pengering. Setelah itu, sosis dikemas dalam plastik PP dengan ketebalan $0.8 \mathrm{~mm}$ dan disimpan dalam freezer pada suhu beku $\left(-10 \pm 2^{\circ} \mathrm{C}\right)$.

\section{Pengujian Kualitas Sosis}

Sosis daging sapi yang telah disimpan dalam freezer dengan suhu $-10 \pm 2^{\circ} \mathrm{C}$, kemudian dilakukan pengujian kualitas yang meliputi uji TPC (Fardiaz, 1993), TVB (Kasmadiharja, 2008), TBA (Apriyantono et al, 1989), $\mathrm{pH}$ (AOAC, 1995) dengan $\mathrm{pH}$ meter (Eutech 1280991), dan warna menggunakan Chroma Meter Konika Minolta CR 400. Masing-masing analisis dilakukan pada bulan ke- 0, 1, 2, 3, dan 4 . Pengujian bulan ke-0 dilakukan setelah sampel disimpan selama 3 hari pada suhu $10 \pm 2^{\circ} \mathrm{C}$ dan pengujian bulan berikutnya dilakukan setelah 30 hari penyimpanan.

Penelitian ini menggunakan Rancangan Acak Lengkap (RAL) dengan satu faktor, yaitu variasi konsentrasi oleoresin daun jeruk purut oleoresin $(0 \% ; 0.01 \%$; dan $0.075 \%$ ) dengan ulangan sampel sebanyak dua kali dan tiap-tiap sampel dilakukan dua kali ulangan analisis. Data yang diperoleh dianalisis menggunakan ANOVA $(\alpha=0.05)$. Jika terdapat perbedaan, maka akan dilanjutkan dengan uji Duncan Multiple Range Test (DMRT) pada tingkat $\alpha=0.05$.

\section{HASIL DAN PEMBAHASAN}

\section{Total Plate Count (TPC)}

Dari hasil uji TPC yang ditunjukkan dalam Gambar 1 diketahui bahwa pada bulan ke-0, sampel dengan perlakuan konsentrasi 0\% (kontrol) memiliki jumlah cemaran tertinggi. Selama penyimpanan, jumlah cemaran mikroba pada sampel semakin meningkat. Pada bulan ke-2, jumlah cemaran paling kecil ditunjukkan oleh sampel konsentrasi $0.01 \%$ dan nilainya berbeda nyata terhadap semua sampel. Pada ketiga sampel terjadi peningkatan jumlah mikroba yang sebanding dengan lama penyimpanannya. Meningkatnya jumlah cemaran mikroba pada sosis daging sapi dapat disebabkan oleh meningkatnya kadar air pada sosis. Menurut Kasmadiharja (2008), sosis daging sapi mengalami peningkatan kadar air selama penyimpanan karena permeabilitas gas dan uap air pada kemasan. Produk pangan dengan kadar air tinggi akan cepat mengalami kebusukan karena jumlah air bebas yang 
dapat digunakan oleh mikroba untuk pertumbuhannya $\left(a_{w}\right)$ semakin tinggi.

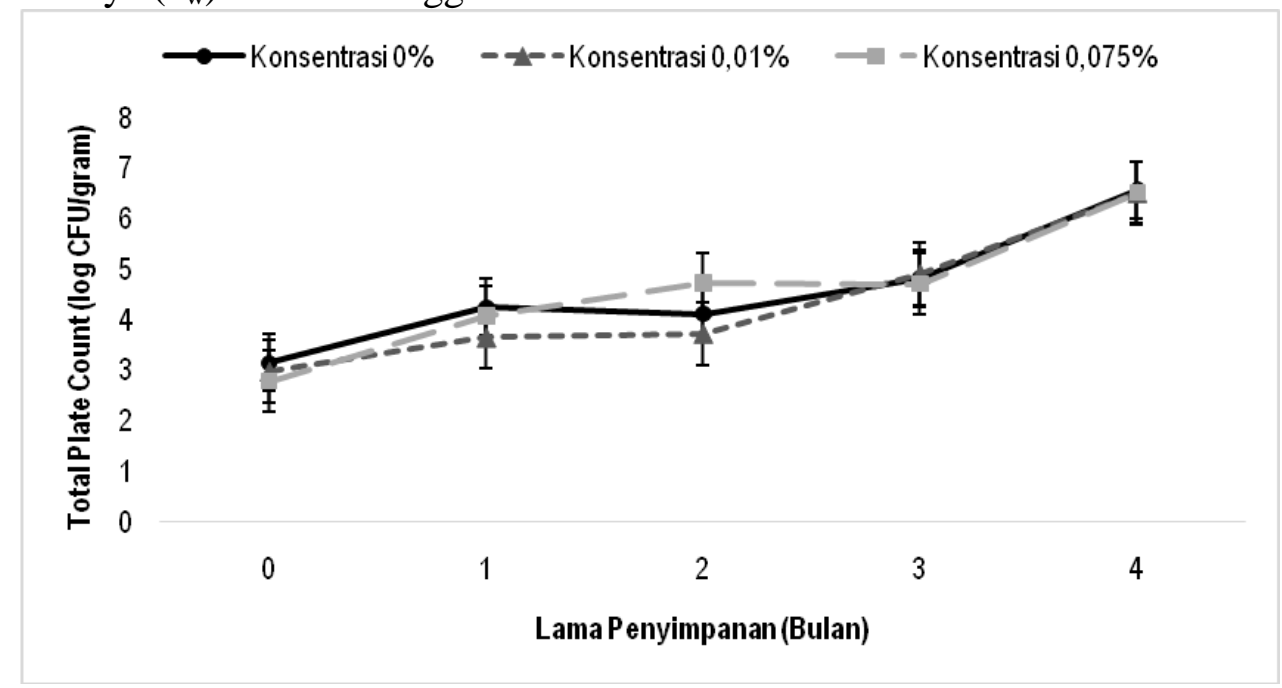

Gambar 1. Total Plate Count Sosis Daging Sapi dengan Edible Coating Oleoresin Daun Jeruk Purut Dua Tahap Selama Penyimpanan pada Suhu $-10 \pm 2{ }^{\circ} \mathrm{C}$

Semakin lama penyimpanan, jumlah mikroba semakin meningkat hingga mencapai $6.5 \log \mathrm{CFU} / \mathrm{g}$. Hal ini telah melampaui batas standar cemaran mikroba yang ditetapkan SNI (1995), yaitu maksimal $10^{5} \mathrm{koloni} / \mathrm{g}$ atau $5 \mathrm{log} \mathrm{koloni} / \mathrm{g}$. Hasil tersebut menunjukkan bahwa seluruh sampel sosis daging sapi masih memenuhi standar mutu SNI hingga 3 bulan lama penyimpanan pada suhu $-10 \pm 2{ }^{\circ} \mathrm{C}$ berdasarkan jumlah cemaran mikrobanya. Abou-Arab dan Ferial (2010) menyatakan aroma busuk pada daging mulai terdeteksi apabila jumlah bakteri telah melebihi $8 \log \mathrm{CFU} / \mathrm{g}$, dimana $7 \log \mathrm{CFU} / \mathrm{g}$ merupakan batas maksimal jumlah mikroba yang dapat diterima. Ketiga sampel sosis belum menunjukkan kebusukkan yang nyata karena tidak adanya lendir maupun bau busuk hingga 4 bulan penyimpanan dan jumlah mikroba belum mencapai $8 \log \mathrm{CFU} / \mathrm{g}$.

Pada penelitian ini oleoresin daun jeruk purut berperan sebagai senyawa antimikroba karena adanya sitronelal, sitronelol, linalool, limonene, dan $\beta$-pinena (Achmad, 2012; Munawaroh, 2010; Chanthanphon, et al., 2008). Senyawa aktif yang terkandung dalam daun jeruk purut mayoritas merupakan senyawa monoterpena (Kotan et al., 2007; Mulyani et al., 2009). Adanya senyawa monoterpena khususnya sitronelal menyebabkan pertumbuhan mikroba terhambat karena sel bakteri mengalami lisis (Mulyani et al., 2009).
Menurut Marcos et al. (2013), keefektifan kemasan antimikroba tergantung pada jenis makanan yang dikemas, polimer pembentuk film, dan jenis antimikroba dan konsentrasinya. Hal tersebut akan menentukan laju difusi dan efisiensi antimikroba.

\section{Total Volatile Base (TVB)}

Pada Gambar 2 menunjukkan terjadi kenaikan nilai TVB pada tiap sampel selama penyimpanan. Peningkatan nilai TVB pada sosis terjadi karena adanya senyawa penyebab kebusukan seperti amonia, $\mathrm{H}_{2} \mathrm{~S}$ dan senyawa volatil lainnya. Kenaikan TVB yang lebih besar pada sampel konsentrasi 0\% dapat dipengaruhi oleh meningkatnya jumlah nitrogen yang terbentuk akibat pembusukkan seperti perombakan molekul-molekul protein yang menyebabkan meningkatnya jumlah total nitrogen terukur selama penyimpanan. Meningkatnya nilai total mikroba selama penyimpanan menyebabkan degradasi protein oleh mikroba berlangsung semakin cepat sehingga meningkatkan jumlah amonia dan senyawa volatil lainnya yang menjadi indikator kebusukan pada bahan dan menyebabkan nilai TVB pada sampel konsentrasi $0 \%$ meningkat. Selain itu, proses pembusukkan yang terus berlangsung selama penyimpanan dan terus menghasilkan amonia dapat tertahan dalam kemasan sehingga akumulasi jumlah amonia yang terus 


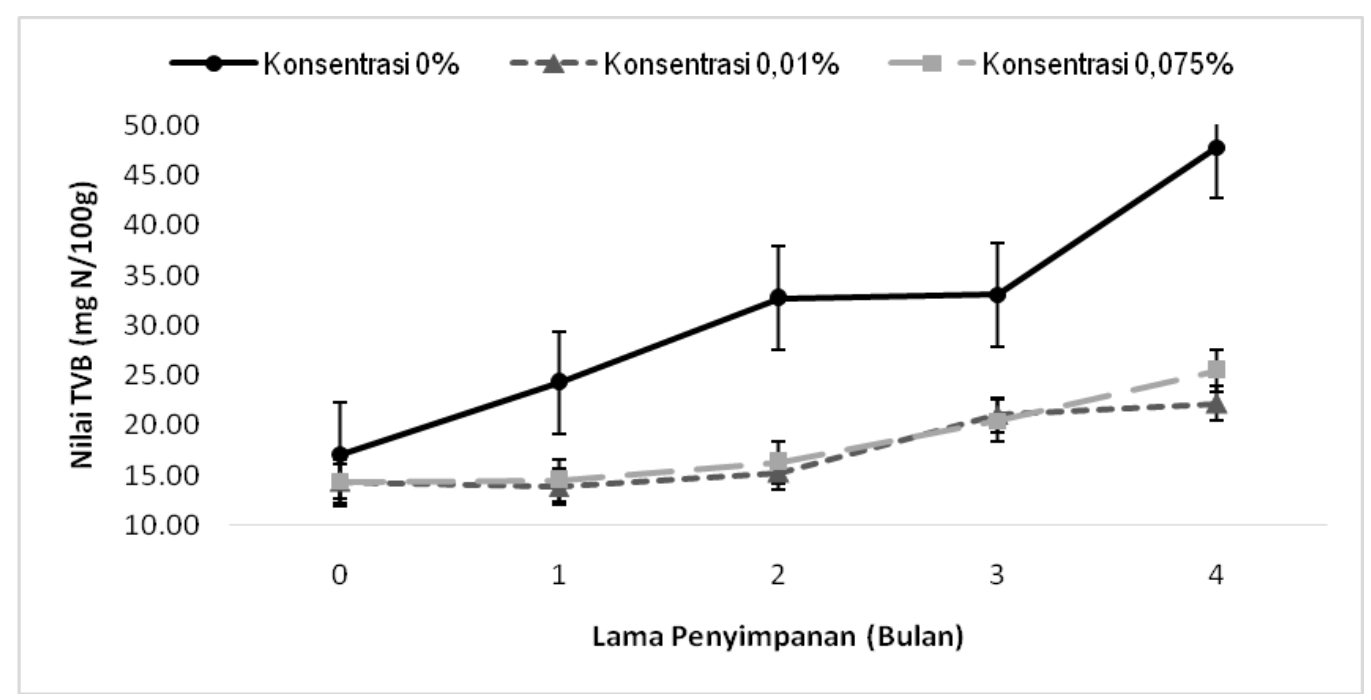

Gambar 2. Nilai TVB Sosis Daging Sapi dengan Edible Coating Oleoresin Daun Jeruk Purut Dua Tahap Selama Penyimpanan pada Suhu $-10 \pm 2{ }^{\circ} \mathrm{C}$

bertambah akan terikat pada bahan. Karena kondisinya yang jenuh, akumulasi jumlah amonia tersebut menyebabkan nilai basa yang terukur meningkat lebih cepat (Kasmadiharja, 2008).

Nilai TVB pada sampel konsentrasi $0.01 \%$ dan $0.075 \%$ secara signifikan jauh lebih rendah dibandingkan sampel konsentrasi $0 \%$. Hal ini menunjukkan bahwa penambahan oleoresin daun jeruk purut dua tahap mampu menghambat peningkatan nilai TVB. Hasil tersebut serupa dengan penelitian Ali et al., (2010) yang menambahkan propolis sebagai pengawet alami pada sosis dimana sampel yang ditambahkan propolis mampu bertahan hingga 21 hari penyimpanan pada suhu dingin, sementara sampel kontrol telah menunjukkan kerusakan protein yang tinggi pada hari ke-15.

Besarnya nilai TVB yang mengindikasikan kerusakan pada daging berdasarkan EOS (Egyptian Organization for Standardization and Quality), yaitu $20 \mathrm{mg}$ N/100 g sampel (Amin, 2012), sedangkan Kasmadiharja (2008) menyatakan nilai TVB sebesar 20-30 mg N/100 g untuk daging yang mulai busuk, dan $30 \mathrm{mg} \mathrm{N} / 100 \mathrm{~g}$ untuk daging yang telah busuk. Bila dibandingkan dengan hasil yang diperoleh, pada bulan ke-2 sampel konsentrasi 0\% telah menunjukan kebusukan karena senyawa volatil yang terdeteksi telah mencapai $30 \mathrm{mg} \mathrm{N} / 100 \mathrm{~g}$ sampel. Sedangkan sampel dengan penambahan oleoresin konsentrasi $0.01 \%$ dan $0.075 \%$ mampu menghambat kerusakan protein hingga 4 bulan masa penyimpanan.

\section{Derajat Keasaman (pH)}

Pada Gambar 3 menunjukkan terjadi perubahan $\mathrm{pH}$ pada tiap sampel selama penyimpanan. Pada sampel konsentrasi $0 \%$, nilai $\mathrm{pH}$ mengalami kenaikan yang cukup kecil sebesar 6.32 di bulan ke-0 menjadi 6.37 di bulan ke-4, tidak berbeda nyata di tiap bulannya. Hasil ini jauh lebih stabil dibandingkan dengan sampel konsentrasi $0.01 \%$ dan $0.075 \%$. Namun pada sampel konsentrasi $0.075 \%$ penurunan $\mathrm{pH}$ yang ditunjukkan tidak signifikan selama penyimpanan. Perubahan nilai $\mathrm{pH}$ yang hampir sama pada kedua sampel konsentrasi $0.01 \%$ dan $0.075 \%$ mengindikasikan bahwa mikroba yang tumbuh selama penyimpanan tidak jauh berbeda. Nilai pH pada bulan ke-1 mengalami penurunan pada kedua sampel. Menurut Osheba et al. (2013), penurunan pH dapat disebabkan oleh pemecahan glikogen menjadi asam laktat oleh mikroba selama penyimpanan. Penurunan $\mathrm{pH}$ juga terjadi pada sosis daging bebek dengan penggunaan bawang putih sebagai antioksidan alami dalam penelitian Dewi et al., (2010).

Meningkatnya laju degradasi protein mengakibatkan kenaikan $\mathrm{pH}$ di bulan berikutnya pada sampel konsentrasi $0.01 \%$ dan $0.075 \%$. Hal ini dipengaruhi oleh 


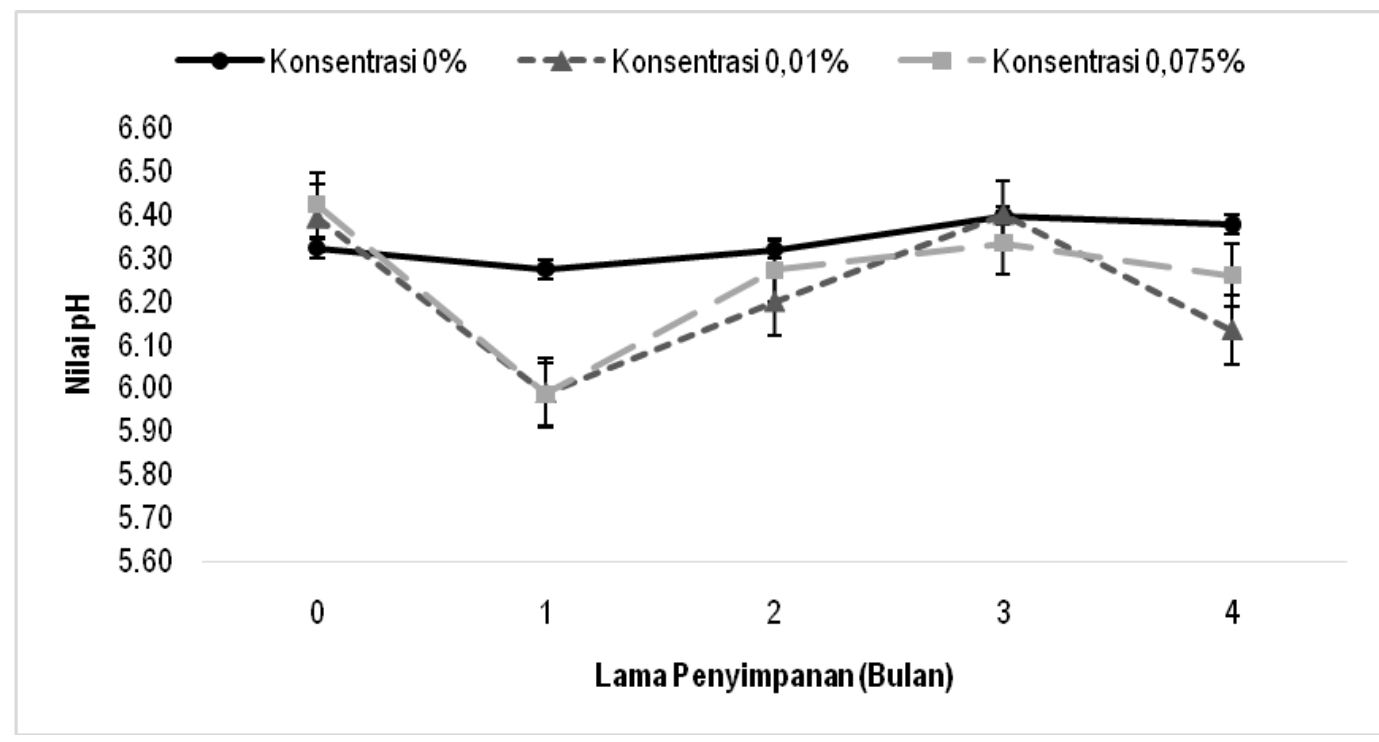

Gambar 3. Nilai pH Sosis Daging Sapi dengan Edible Coating Oleoresin Daun Jeruk Purut Dua Tahap Selama Penyimpanan pada Suhu $-10 \pm 2{ }^{\circ} \mathrm{C}$

peningkatan pertumbuhan mikroba dan kadar air selama penyimpanan. Menurut Kasmadiharja (2008), kenaikan tersebut akan mempengaruhi laju pembusukan yang terjadi dalam menghasilkan senyawa basa seperti $\mathrm{NH}_{3}, \mathrm{H}_{2} \mathrm{~S}$, trimetilamin, dan senyawa volatil lainnya yang menyebabkan naiknya nilai $\mathrm{pH}$. Namun akumulasi asam laktat yang terbentuk selama penyimpanan menyebabkan nilai $\mathrm{pH}$ daging mengalami penurunan kembali setelah 3 bulan penyimpanan (Takasari, 2008).

Nilai $\mathrm{pH}$ pada daging sapi berkisar antara 5.4-6.0 (Quasem et al., 2009), sementara sosis berkisar antara 5.8-6.2 (Indriyani, 2007). Sampel konsentrasi 0\% yang memiliki kisaran pH 6.27-6.40 selama masa penyimpanan dapat menjadi lingkungan yang sesuai untuk tumbuhnya mikroba. Nilai pH optimum pertumbuhan bakteri yaitu 6.57.5 , sementara bakteri asam laktat mampu tumbuh pada pH 3.0 hingga 6.0 (Fardiaz, 1992). Sampel konsentrasi 0\% juga menunjukkan aktivitas kerusakan mikrobiologis yang meningkat seiring dengan lamanya penyimpanan. Selain itu, tingginya tingkat kerusakan protein yang ditunjukkan pada hasil uji TVB mengakibatkan kenaikan pH karena hasil degradasi protein yang bersifat basa. Hal inilah yang kemudian dapat membuat sampel konsentrasi $0 \%$ terlihat memiliki nilai $\mathrm{pH}$ yang stabil.

\section{Nilai Thiobarbituric Acid (TBA)}

Pada Gambar 4 ditunjukkan bahwa terjadi peningkatan nilai TBA sampel sosis pada semua perlakuan konsentrasi seiring semakin lamanya waktu penyimpanan walaupun peningkatan terjadi secara fluktuatif. Berbeda dengan sampel perlakuan konsentrasi lainnya, sampel dengan konsentrasi $0 \%$ menunjukkan nilai TBA yang cukup tinggi di bulan ke-0 dan berbeda nyata terhadap sampel konsentrasi $0.01 \%$ dan $0.075 \%$. Hal ini dapat menunjukkan bahwa pada sampel konsentrasi $0 \%$ terjadi kerusakan oksidatif yang cukup tinggi akibat pengaruh penyimpanan. Sampel dengan penambahan oleoresin konsentrasi $0.01 \%$ dan $0.075 \%$ menunjukkan nilai yang lebih kecil dari konsentrasi $0 \%$ pada bulan ke-0 karena adanya aktivitas antioksidan yang dimiliki oleh daun jeruk purut.

Menurut Widowati et al. (2005), daun jeruk purut mempunyai aktivitas antioksidan sebesar $23.6 \%$ dengan menggunakan metode super-oksida dismutase atau SOD. Senyawa fenol yang ada pada daun jeruk purut menekan pembentukan radikal bebas atau Radical Oxygen Species (ROS) dengan cara menghambat enzim, pengkelatan ion logam (metal ion chelating) yang terlibat produksi radikal bebas. Hal tersebut juga telah diteliti oleh Aziman et al., (2012) bahwa senyawa fenol dalam ekstrak etanol daun jeruk purut 


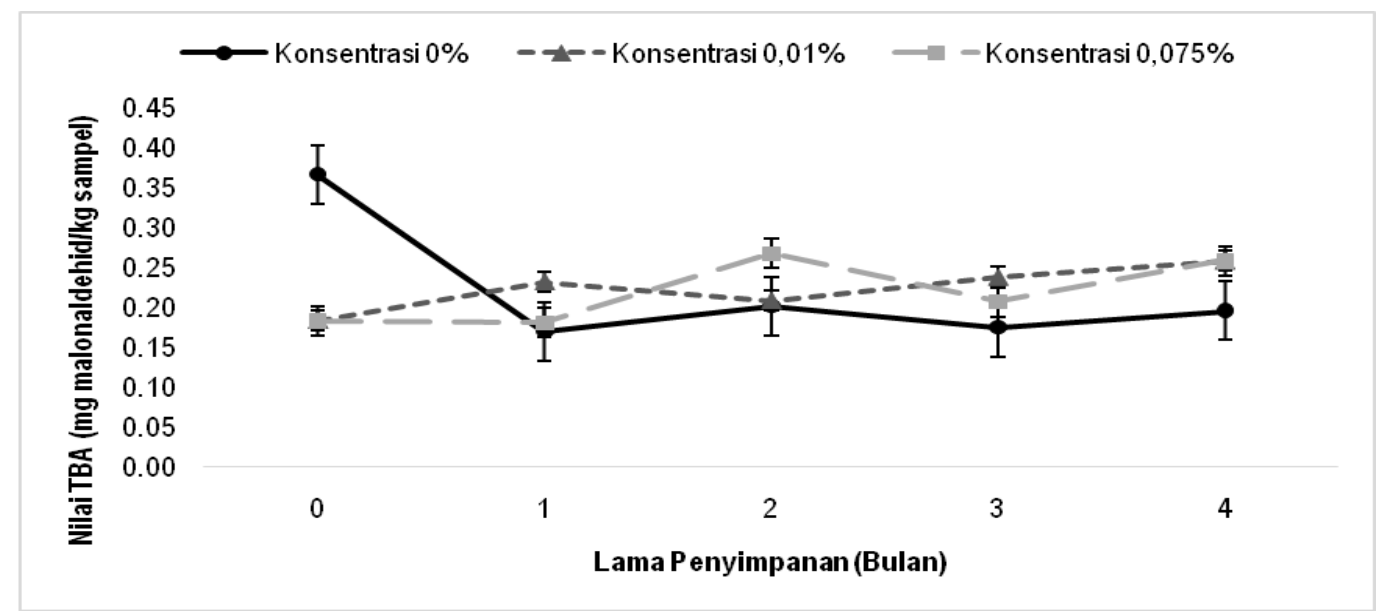

Gambar 4. Nilai TBA Sosis Daging Sapi dengan Edible Coating Oleoresin Daun Jeruk Purut Dua Tahap Selama Penyimpanan pada Suhu $-10 \pm 2{ }^{\circ} \mathrm{C}$

bertindak sebagai donor elektron karena menunjukkan hasil tertinggi pada uji Ferric Reducing Antioxidant Power (FRAP). Dengan adanya aktivitas antioksidan daun jeruk purut, proses autooksidasi lipid pada sosis dapat dicegah ataupun dikurangi sehingga nilai TBA yang pada sampel konsentrasi $0.01 \%$ dan $0.075 \%$ lebih rendah dibandingkan sampel konsentrasi $0 \%$.

Seperti yang ditunjukkan pada Gambar 4, nilai TBA pada sampel konsentrasi $0 \%$ lebih rendah dibandingkan sampel konsentrasi $0.01 \%$ dan $0.075 \%$ selama penyimpanan bulan ke-1 hingga bulan ke-4. Meskipun lebih rendah, nilai TBA pada sampel konsentrasi 0\% tidak berbeda nyata terhadap sampel konsentrasi $0.01 \%$ dan 0.075\%. Menurut Estiningtyas (2010), nilai TBA yang rendah bukan berarti lemak belum mengalami oksidasi, karena aldehid yang terakumulasi sudah bereaksi dengan senyawa lain atau menguap baik selama penyimpanan atau proses thawing. Menurut Sediek et al., (2012), senyawa malonaldehid dapat mengalami oksidasi lanjut menjadi senyawa organik lain hasil oksidasi lemak. Penyebab lain yang mungkin terjadi adalah dekomposisi malonaldehid oleh bakteri seperti Enterobacteriaceae yang memiliki kemampuan memecah secara selektif dan memanfaatkan senyawa karbonil termasuk malonaldehid. Pola nilai TBA yang serupa juga ditunjukkan oleh sosis dengan edible coating kitosan dan minyak jintan dimana pada akhir penyimpanan nilai TBA mengalami penurunan walau tidak signifikan (Krkic et al., 2013).

Sitronelal merupakan senyawa monoterpena yang memiliki gugus aldehid (Singh et al., 2006; Jirapakkul et al., 2013). Uji TBA mengidentifikasi adanya senyawa malonaldehid yang terdapat maupun yang terbentuk selama penyimpanan. Malonaldehid terbentuk dari reaksi oksidasi lipid atau oksidasi lemak pada tahap lanjut. Adanya sitronelal yang memiliki gugus aldehid dapat bereaksi dengan asam thiobarbiturat (TBA) sehingga membentuk warna merah yang lebih pekat. Hal tersebut menyebabkan nilai TBA pada sampel konsentrasi $0.01 \%$ dan $0.075 \%$ lebih tinggi dibandingkan sampel konsentrasi 0\%. Meski demikian, kenaikan nilai TBA yang terjadi pada sampel konsentrasi $0.01 \%$ dan $0.075 \%$ tidak signifikan selama 4 bulan penyimpanan.

Penambahan oleoresin daun jeruk purut pada edible coating menunjukkan hasil yang lebih baik dari penelitian yang dilakukan Sarfraz et al., (2013) dan Salem (2013) yang menggunakan ekstrak daun kemangi dan tepung kulit tomat sebagai pengawet alami pada sosis. Sampel dengan perlakuan terbaik memiliki nilai TBA 0.34 $\mathrm{mg}$ malonaldehid/kg (Sarfraz et al., 2013) dan $0.853 \mathrm{mg}$ malonaldehid/kg (Salem, 2013) pada akhir penyimpanan suhu beku. Berdasarkan nilai TBA selama penyimpanan, semua sampel perlakuan konsentrasi penambahan oleoresin daun jeruk purut belum melebihi $2 \mathrm{mg}$ malonaldehid/kg sampel. Menurut Salem (2013), nilai TBA 


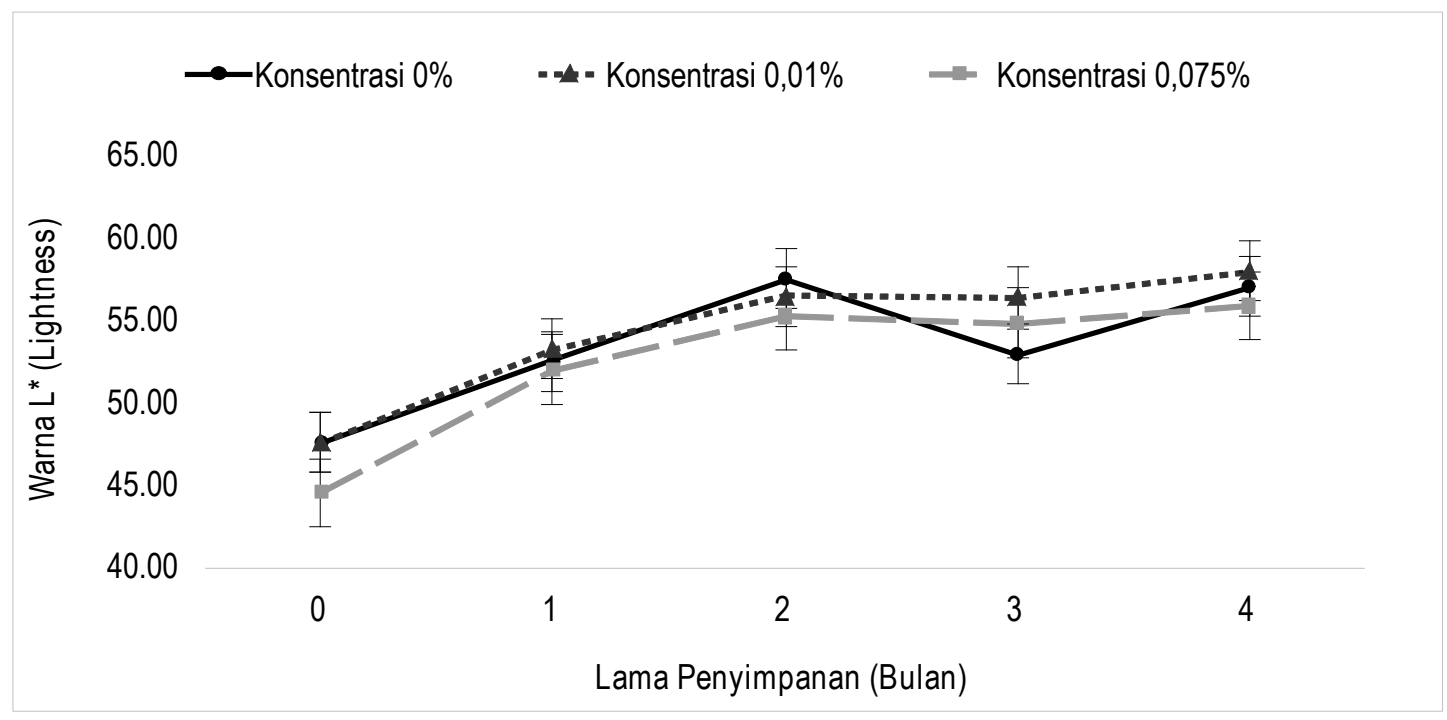

Gambar 5. Intensitas Warna L* (Lightness) Sosis Daging Sapi dengan Edible Coating Oleoresin Daun Jeruk Purut Dua Tahap Selama Penyimpanan pada Suhu -10 \pm $2^{\circ} \mathrm{C}$

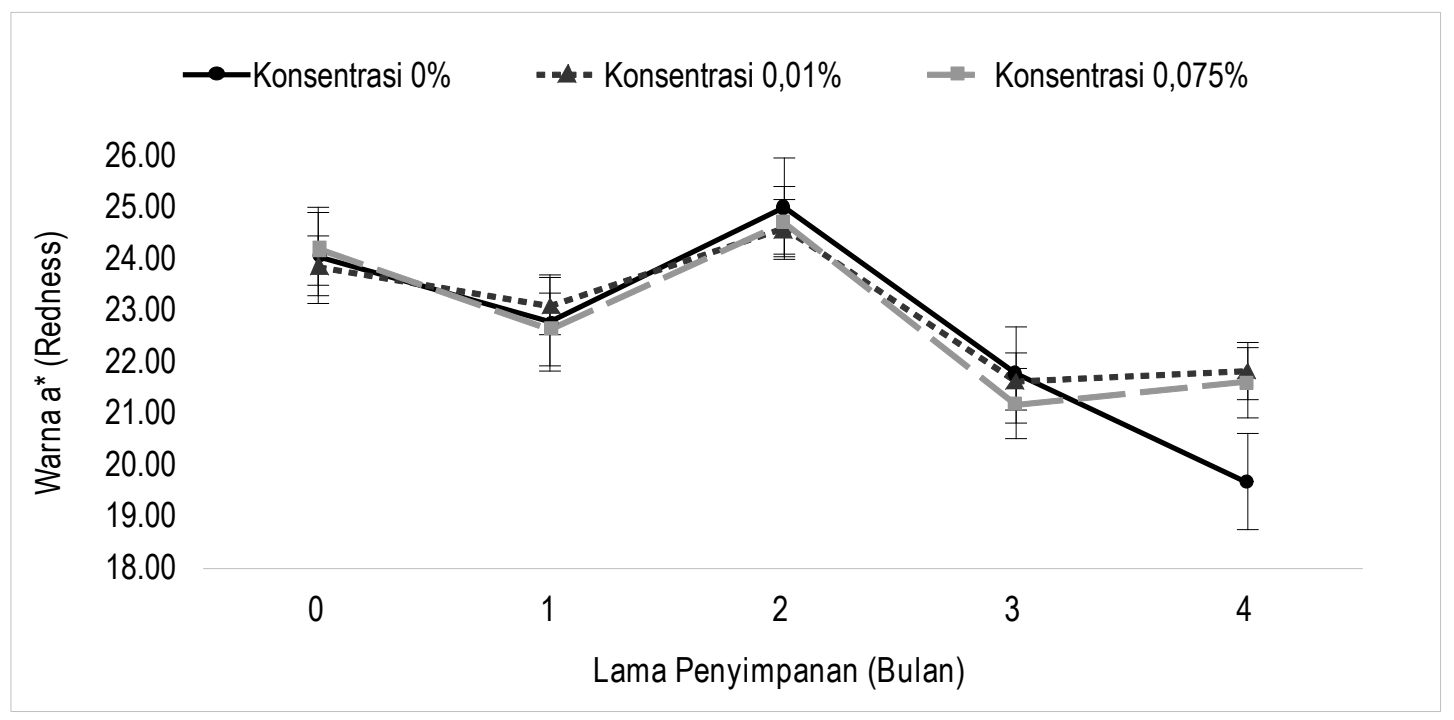

Gambar 6. Intensitas Warna $\mathrm{a}^{*}$ (Redness) Sosis Daging Sapi dengan Edible Coating Oleoresin Daun Jeruk Purut Dua Tahap Selama Penyimpanan pada Suhu -10 \pm $2^{\circ} \mathrm{C}$

minimum yang dapat menimbulkan offflavour pada daging dan produk olahannya, yaitu sebesar $2 \mathrm{mg}$ malonaldehid/kg dan pada umumnya, nilai TBA pada sosis beku tidak melebihi $0.9 \mathrm{mg}$ malonaldehid $/ \mathrm{kg}$.

\section{Warna}

Berdasarkan hasil análisis yang dilakukan pada sosis daging sapi, terjadi penurunan intensitas warna baik a (redness) (Gambar 6) dan b (yellowness) (Gambar 7) pada sosis selama 4 bulan penyimpanan pada suhu beku, sedangkan nilai L (lightness) mengalami kenaikan (Gambar 5). Penurunan intensitas warna merah dan kuning terjadi pada perlakuan konsentrasi $0 \%$ maupun perlakuan penambahan oleoresin daun jeruk purut dua tahap $0.01 \%$ dan $0.075 \%$. Begitu juga dengan kenaikan tingkat kecerahan terjadi pada semua sampel.

Pengaruh penambahan oleoresin pada edible film sosis daging sapi pada karakteristik fisik berupa warna tidaklah signifikan. Hal ini ditunjukkan dengan tidak 


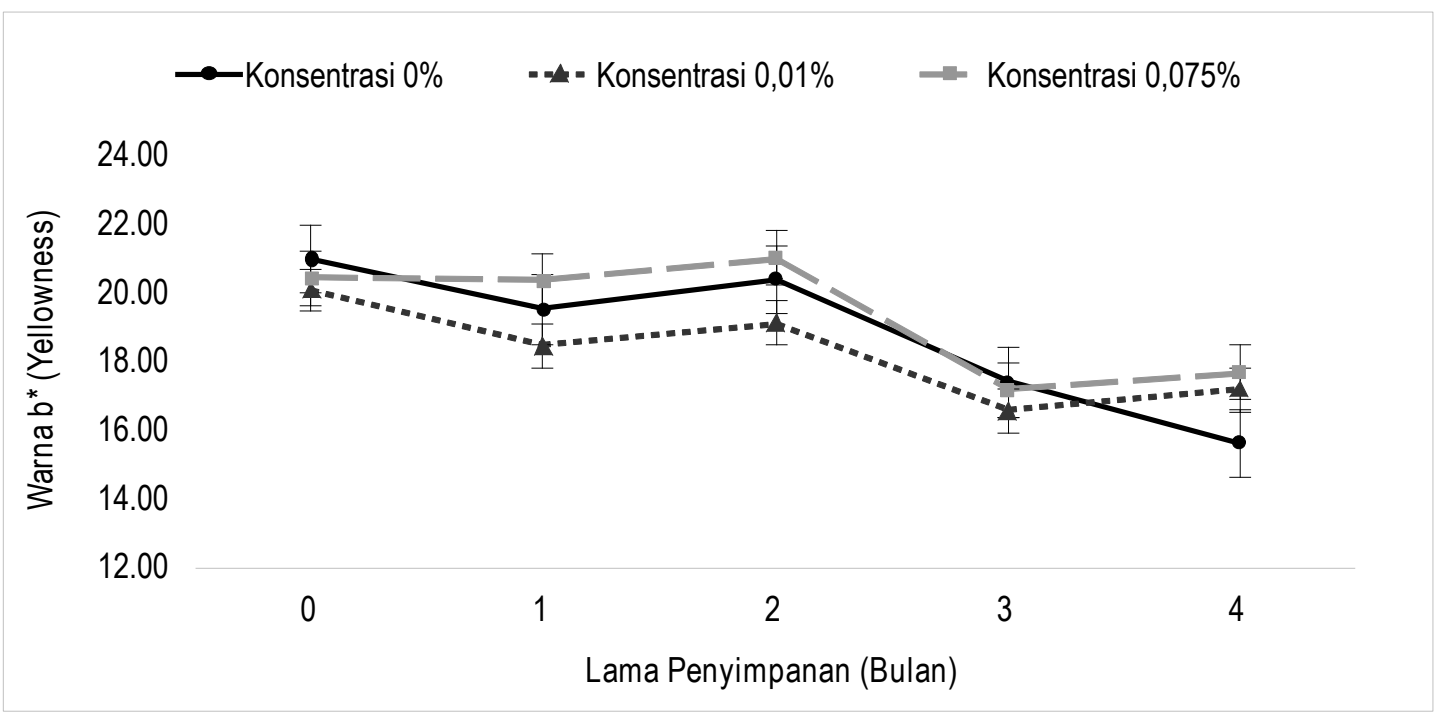

Gambar 7. Intensitas Warna b* (Yellowness) Sosis Daging Sapi dengan Edible Coating Oleoresin Daun Jeruk Purut Dua Tahap Selama Penyimpanan pada Suhu -10 \pm $2^{\circ} \mathrm{C}$

adanya perbedaan yang nyata terhadap kecerahan dan warna merah dari sosis daging sapi pada bulan ke-0. Namun, penambahan konsentrasi yang lebih besar dapat menurunkan tingkat kecerahan sosis daging sapi yang juga dapat mempengaruhi warna merah sehingga terlihat lebih pekat walau secara statistik tidak terlihat adanya perbedaan yang nyata.

Kenaikan intensitas kecerahan
maupun penurunan intensitas warna kemerahan dan kekuningan yang terjadi pada sampel sosis daging sapi dengan variasi konsentrasi penambahan oleoresin daun jeruk purut pada edible film sejalan dengan penelitian yang dilakukan oleh Wardana dan Widyaningsih (2006). Dalam penelitiannya, sosis daging sapi dengan aplikasi edible film yang ditambahkan ekstrak kubis ungu mengalami kenaikan tingkat kecerahan dan penurunan intensitas warna kemerahan dan kekuningan seiiring dengan lamanya masa penyimpanan karena pengaruh dari metabolit mikroba. Proses pembekuan juga dapat menimbulkan kerusakan karena terbentuknya kristal es yang mampu menyebabkan kerusakan mekanis sel penyusun bahan. Kerusakan sel tersebut yang kemudian menyebabkan denaturasi warna. Menurut Osheba (2013), penurunan intensitas warna juga disebabkan oleh oksidasi oksimyoglobin menjadi metmyoglobin sehingga mempengaruhi warna merah pada sosis.
Berdasarkan hasil pengujian warna sosis daging sapi terlihat bahwa terjadi kenaikan intensitas warna L (Lightness) dan penurunan intensitas warna $\mathrm{a}^{*}$ (Redness), dan $b^{*}$ (Yellowness) selama masa penyimpanan pada semua sampel. Sampel kontrol mengalami penurunan intensitas warna merah yang lebih tajam dan signifikan pada akhir masa penyimpanan dimana warna merah sangat berkaitan dengan kualitas produk daging olahan secara sensori. Sementara sampel konsentrasi $0.01 \%$ memiliki pola kenaikan intensitas kecerahan dan penurunan intensitas warna merah dan kuning yang sama dengan sampel konsentrasi $0.075 \%$ serta tidak menunjukkan beda nyata selama penyimpanan. Maka perlakuan penambahan oleoresin daun jeruk purut sebesar $0.01 \%$ sudah cukup mampu mempertahankan warna pada sosis daging sapi yang disimpan pada suhu beku.

\section{KESIMPULAN}

Penambahan oleoresin daun jeruk purut dua tahap pada edible coating yang diaplikasikan pada sosis daging sapi berpengaruh terhadap tingkat kerusakan mikrobiologis dan oksidatif selama penyimpanan suhu beku $\left(-10 \pm 2^{\circ} \mathrm{C}\right)$. Berdasarkan nilai TVB dan TBA sosis daging sapi dengan perlakuan oleoresin daun jeruk purut dua tahap belum menunjukkan tingkat 
kebusukan dan ketengikan sampai bulan ke-4 serta mampu mempertahankan $\mathrm{pH}$ dan warna terutama intensitas warna merah pada sosis. Penambahan oleoresin daun jeruk purut dua tahap pada edible coating dapat meningkatkan umur simpan sosis daging sapi.

\section{UCAPAN TERIMA KASIH}

Peneliti mengucapkan terimakasih kepada Direktorat Jendral Pendidikan Tinggi yang telah membiayai penelitian ini melalui Program Desentralisasi Penelitian Unggulan Perguruan Tinggi 2012.

\section{DAFTAR PUSTAKA}

Abou-Arab EA, Ferial MA. 2010. Effect of natural antioxidants on the stability of ostrich meat during storage. Grasas Aceites 61: 102-108. DOI: 10.3989/gya.042909

Achmad F. 2012. Proses Ekstraksi Oleoresin Daun Jeruk Purut (Citrus hystrix DC) Dengan Dua Tahap : Optimasi Rendemen dan Pengujian Karakteristik Mutu [Skripsi]. Surakarta: Fakultas Pertanian, Universitas Sebelas Maret.

Ali FH, Gehan MK, Osama AA. 2010. Propolis as a natural decontaminant and antioxidant in fresh oriental sausage. Vet. Ital 46: 167-172.

Amin RA. 2012. Effect of bio preservation as a modern technology on quality aspects and microbial safety of minced beef. Global J. Biotech. \& Biochem 7: 38-49. DOI: 10.5829/idosi.gjbb.2012.7.2.64154.

Apriyantono A, Fardiaz D, Puspitasari NL, Sedarnawati, Budiyanto S. 1989. Petunjuk Laboratorium Analisis Pangan. Pusat Antar Universitas Pangan dan Gizi. IPB, Bogor.

Association of Official Analytical Chemist (AOAC). 1995. Official Methods of Analysis. 16th Edition. Washington DC.

Aziman N, Abdullah N, Noor ZM, Zulkifli KS, Kamarudin WSSW. 2012. Phytochemical constituents and in vitro bioactivity of ethanolic aromatic herb extracts. Sains Malaysiana 41: $1437-$ 1444.

Chanthaphon S, Chanthachum S, Hongpattarakere T. 2008. Antimicrobial activities of essential oils and crude extracts from tropical citrus spp. against food-related microorganism. Songklanakarin J. Sci. Technol 30:125131.

Dewan Standarisasi Nasional. 1995. Sosis. SNI 01-3820-1995. Dewan Standarisasi Nasional, Jakarta.

Dewi M, Huda N, Ismail N. 2010. Use of fresh garlic and garlic powder in duck sausages during refrigerated storage. As. J. Food Ag-Ind 3:526-534.

Estiningtyas HR. 2010. Aplikasi Edible Film Maizena Dengan Penambahan Ekstrak Jahe Sebagai Antioksidan Alami Pada Coating Sosis Sapi [Skripsi]. Surakarta: Fakultas Pertanian, Universitas Sebelas Maret.

Fardiaz S. 1992. Mikrobiologi Pengolahan I. Pusat Antar Universitas Pangan dan Gizi IPB, Bogor.

Fardiaz S. 1993. Analisis Mikrobiologi Pangan. Raja Grafindo Persada, Jakarta.

Indriyani, Brida. 2007. Karakteristik Sosis Sapi dengan Menggunakan Bahan Dasar Tepung Daging Sapi [Skripsi]. Bogor: Fakultas Peternakan, Institut Pertanian Bogor.

Jirapakkul W, Tinchan P, Chaiseri S. 2013. Effect of drying temperature on key odourants in kaffir lime (Citrus hystrix D.C., Rutaceae) leaves. Int. J. Food Sci. Tech 48: 143-149. DOI: 10.1111/j.13652621.2012.03170.x

Kasmadiharja H. 2008. Kajian Penyimpanan Sosis, Naget Ayam dan Daging Ayam Berbumbu Dalam Kemasan Polipropilen Rigid [Skripsi]. Bogor: Fakultas Pertanian, Institut Pertanian Bogor.

Kotan R, Kordali S, Cakir A. 2007. Screening of antibacterial activities of twenty-one 
oxygenated monoterpenes. $\mathrm{Z}$. Naturforsch 62: 507-513.

Krkic N, Sojic B, Lazic V, Petrovic L, Mandic A, Sedej I. 2013. Effect of chitosan-caraway coating on lipid oxidation of traditional dry fermented sausage. Food Control 32: 719-723. DOI : 10.1016/j.foodcont.2013.02.006.

Marcos B, Aymerich T, Garriga M, Arnau J. 2013. Active packaging containing nisin and high pressure processing as postprocessing listericidal treatment for convenience fermented sausages. Food Control 30: 325-330. DOI: 10.1016/j.foodcont.2012.07.019.

Mulyani S, Susilowati, Hutabarat MM. 2009. Analisis GC-MS dan daya anti bakteri minyak atsiri Citrus amblycarpa (Hassk) Ochse. Majalah Farmasi Indonesia 20: $127-132$.

Munawaroh S, Handayani PA. 2010. Ekstraksi Minyak Daun Jeruk Purut (Citrus hystrix D.C.) dengan Pelarut Etanol dan N-Heksana. Jurnal Kompetensi Teknik 2: 73-78.

Nanasombat S, Lohasupthawee P. 2005. Antibacterial activity of crude ethanolic extracts and essential oils of spices against salmonellae and other enterobacteria. KMITL Sci. Tech. J 5 : 527-538.

Osheba AS, Jussien SA, El-Dashlouty AA. 2013. Evaluation of some vegetal colloids on the quality attributes of beef sausage. Adv. J. Food Sci. Technol 5: 743-751.

Ozcakmak S, Ozturk E. 2012. Use of edible films containing plant and spice essential oils with fungistatic and fungicidal effects in foods. Akademik Gida 10: 6669.

Quasem JM, Mazahreh AS, Al-Shawabkeh AF. 2009. nutritive value of seven varieties of meat products (sausage) produced in Jordan. Pak. J. Nutr 8: 332334.

Salem RH. 2013. Quality characteristics of beef sausages with tomato peel as a colour and functional additive during frozen storage. World Appl. Sci. J 22: 1085-1093.

10.5829/idosi.wasj.2013.22.08.7294.

Sarfraz Z, Anjum FM, Khan MI, Arshad MS, Nadeem M. 2011. Characterization of basil (Ocimum basilicum L.) parts for antioxidant potential. Afr. J. Food Sci. Technol 2: 204-213.

Sediek LEL, Wafaa, Abozeid MM, Alkhalifah DH, Farag SEA. 2012. Efficacy of ginger extract (Zingiber officinale) and gamma irradiation for quality and shelf-stability of processed frozen beef sausage. Life Science Journal 9: 448-461.

Singh HP, Batish DR, Kaur D, Kohli RK, Arora K. 2006. Phytotoxicity of the volatile monoterpene citronellal against some weeds. Z. Naturforsch 61: 334340.

Takasari C. 2008. Kualitas Mikrobiologis Daging Sapi Segar dengan Penambahan Bakteriosin dari Lactobacillus sp. Galur SCG 1223 yang Diisolasi dari Susu Sapi [Skripsi]. Bogor: Fakultas Peternakan Institut Pertanian Bogor.

Wardana AA, Widyaningsih TD. 2006. Edible Film Packaging Of Red Cabbage Extract (Brassica Oleracea Var. Capitata L F Rubra) As Bioindicator For Detect Shelf Life Of Sausage [Skripsi]. Malang: Fakultas Teknologi Pertanian, Universitas Brawijaya.

Widowati W, Safitri R, Rumumpuk R, Siahaan M. 2005. Penapisan aktivitas superoksida dismutase pada berbagai tanaman. JKM. 5: 33-47.

Wungsintaweekul J, Sitthithaworn W, Putalun W, Pfeifhoffer HW, Brantner A. 2010. Antimicrobial, antioxidant activities and chemical composition of selected Thai spices. Songklanakarin J. Sci. Techno 32: 589-598. 